\title{
Aetiology of extrahepatic epithelial iron deposits in siderosis in Bantu
}

\author{
W. M. BUCHANAN \\ From the Department of Pathology, University College of Rhodesia, Harari Hospital, Salisbury
}

SYNOPSIS Twenty-seven specimens of human tissue, obtained by operation, were tested to evaluateo the theory that iron uptake by tissues from serum is greater when transferrin is nearly completely saturated than when the degree of saturation is normal.

Samples of each tissue were incubated in autologous serum so prepared that in one instance the $w$ transferrin was $50 \%$ saturated and in the second $90 \%$ saturated with iron containing ${ }^{59} \mathrm{Fe}$.

In all samples the uptake of iron was greater from the transferrin which was $90 \%$ saturated. The uptake by tissues of epithelial origin was significantly greater than that by non-epithelial tissues..$^{\circ}$ Considerable variation in uptake was noted between samples of the same tissue from different $\vec{z}$ individuals. The role of iron stores in the tissue and folic acid deficiency are discussed.

It is concluded that the degree of transferrin saturation is important in determining iron uptake $\frac{\vec{C}}{\circ}$ by tissues, especially in those of epithelial origin, and that such uptake may be modified by tissue: stores and folic acid deficiency.

It is felt that these factors are probably responsible for the extrahepatic parenchymal deposits of iron sometimes found in Bantu subjects with siderosis.

In most cases of siderosis in the Bantu iron deposits are confined to the liver, the reticuloendothelial system, and the small bowel mucosa (Higginson, Gerritsen, and Walker, 1953; Wainwright, 1957). There are, however, a few cases in which iron deposits are present in many glandular tissues. Subjects with this distribution usually, but not invariably, have an associated fine cirrhosis of the liver (Bradlow, Dunn, and Higginson, 1961; Isaacson, Seftel, Keeley, and Bothwell, 1961; Buchanan, 1967). The fact that the widespread deposits of iron in tissue of epithelial origin occasionally occur in the absence of cirrhosis and are uncommon in subjects with postnecrotic cirrhosis (Isaacson et al, 1961; Buchanan, 1967) suggests that cirrhosis itself is not responsible for this phenomenon.

Jandl, Inman, Simmons, and Allen (1959) have shown that the uptake of iron bound to transferrin by rat liver slices is greater when the saturation of transferrin is more than $60 \%$ than when it is less. Inspired by this work Bothwell (1964) suggested that the different patterns of iron distribution seen in siderosis in the Bantu might be determined by the percentage saturation of transferrin. Some support for Bothwell's theory was obtained from necropsy

Received for publication 15 August 1968. findings in a small series of African patients some of whom were known to have a high, and others a윽 normal, percentage saturation of transferrin during life. In those with the high percentage saturation, extrahepatic epithelial deposits or iron were heavy, while in patients with normal percentage saturationo such epithelial deposits were either scanty or com-윽 pletely absent (Buchanan, 1967). Furthermore, in the iron storage diseases, idiopathic haemochromatosiso (Finch and Finch, 1955) and transfusional siderosis (Cappell, 1958-59), in which epithelial deposits of iron are extensive, the percentage saturation of trans $-\rightarrow$ ferrin is high.

The following investigation was carried out in anN attempt to confirm that percentage saturation of transferrin is important in determining iron uptake $N$ in human tissues.

\section{MATERIALS AND METHODS}

The principle behind the experiment was to incubate thin slices of viable human tissue obtained at operation in the 0 patient's own serum. In each case the serum was so treatedo that in one tube the transferrin was approximately $50 \% \mathbb{\mathbb { D }}$ saturated with iron while in a second tube it was approxi-क्ष mately $90 \%$ saturated. The iron added to the transferrin contained ${ }^{59} \mathrm{Fe}$. The radioactivity of the tissue slices was 
measured and compared with a standard and from this the iron uptake by the tissue was calculated. In order to obviate the errors due to non-specific trapping of radioactive serum in the intercellular spaces of the tissues, the serum in the second tube was first so prepared with nonradioactive iron that the same amount of radioactive iron could be added to both tubes to produce approximately $50 \%$ saturation in one tube and approximately $90 \%$ saturation in the second. This meant that the amount of radioactivity in both pieces of tissue due to nonspecific trapping of serum would be approximately the same (if allowance were made for any difference in weight of the tissue) and thus any difference in radioactivity would presumably be due to difference in uptake of radioactive iron by the tissue cells.

Patients were unselected, except in so far as it was necessary to know of the time of the operation at least one day before the test in order to prepare the serum.

The detailed procedure was as follows: approximately $60 \mathrm{ml}$ of blood was withdrawn from the patient and the serum separated. The serum iron was estimated by the method of Bothwell and Mallet (1955) and the unsaturated iron-binding capacity by the method of Bothwell, Jacobs, and Kamener (1959). Eight $\mathrm{ml}$ of serum was measured by pipette into each of two $10 \mathrm{ml}$ polythene tubes which had been previously washed in acid, well rinsed with deionized water, and dried.

Two solutions of ferric ammonium citrate were prepared by the method described by Bothwell et al (1959) for use in the estimation of unsaturated ironbinding capacity with the following modifications. In solution 1 no ${ }^{59} \mathrm{Fe}$ was used in preparing the ferric ammonium citrate and in solution 2 about $100 \mu \mathrm{c}{ }^{59} \mathrm{Fe}$ was used to prepare the ferric ammonium citrate.

The iron content of solution 1 in this series of experiments was $28 \mu \mathrm{g} / \mathrm{ml}$ while that of the three preparations of solution 2 was 25,30 , and $32 \mu \mathrm{g} / \mathrm{ml}$. The $p \mathrm{H}$ value of solution 1 was $8 \cdot 31$ and of the three preparations of solution 2 was $8 \cdot 84,9 \cdot 1$, and $9 \cdot 2$.

In case there should be much difference in $\mathrm{pH}$ between the serum with the low saturation of transferrin and that with the high saturation which could affect the stability of the transferrin-iron system (Surgenor, Koechlin, and Strong, 1949) the $p \mathrm{H}$ values of both were measured in a few cases (Table II).

The mount of iron, $x$, to be added to the $8 \mathrm{ml}$ of serum to produce approximately $50 \%$ saturation of transferrin was calculated from the formula

$$
x=\left(\frac{\mathrm{TIBC}}{2}-\mathrm{SI}\right) \times \frac{8}{100} \mu \mathrm{g}
$$

and the amount of iron, $y$, to be added to the $8 \mathrm{ml}$ of serum to produce approximately $90 \%$ saturation, from the formula

$$
y=(9 / 10 \times \mathrm{TIBC}-\mathrm{SI}) \times \frac{8}{100} \mu \mathrm{g}
$$

where TIBC $=$ the total iron-binding capacity of the serum and SI = the serum iron, both values being expressed as $\mu \mathrm{g} / 100 \mathrm{ml}$ serum. The amount of non- radioactive iron to be added to serum B was $y-x \mu \mathrm{g}$. The volume of iron solution to be added in each case was calculated from the amount of iron required and the iron concentration of the solution by simple proportion.

The non-radioactive iron solution was added to serum $B$ at least three hours before the radioactive solution to allow time for complete stability of the transferrin-iron system. The radioactive iron solution was then added to both sera A and B and the sera allowed to stand at room temperature for about 18 hours before the tissue slices were added. Directly after the iron solution had been added to the serum, they were mixed by repeated inversion of the tubes.

A tissue slicer was constructed on the principle of the Stadie-Riggs microtome (Stadie and Riggs, 1944). This was designed to cut tissue to a thickness of $0.5 \mathrm{~mm}$.

At the time of operation the equipment was taken to a room adjacent to the operating theatre. As soon as the tissue had been removed from the patient it was taken immediately to the side room and slices cut with the Stadie-Riggs microtome. The slices were rinsed in Krebs-Ringer solution and aliquots placed in the tubes containing the serum. The tubes were transferred to the laboratory and placed on a Matburn rotary mixer which was housed inside an incupator. The tubes were then incubated at $37^{\circ} \mathrm{C}$ for three hours while undergoing constant mixing.

When incubation was complete the tissue slices were removed from the serum and washed in three changes of Krebs-Ringer solution. They were then dried carefully between two sheets of blotting paper. Each piece of tissue was weighed to the nearest milligram and placed in a boiling tube with $2 \mathrm{ml}$ of concentrated nitric acid. The acid-tissue mixture was boiled for 15 minutes, the tube being attached to a reflux condenser to reduce loss of radioactive iron in the vapour.

The acid digest, when cool, was decanted into a $10 \mathrm{ml}$ polythene tube. The digest was diluted with deionized water to a volume of $4 \mathrm{ml}$, a mark having previously been made on the tube at that level. The radioactivity of the solution was then measured in a 'well' counter. Each sample was counted for 100 seconds three times and an average of the three counts used for the calculation.

A standard was prepared by measuring a suitable amount of radioactive iron solution (previously referred so as 'solution 2') into an identical polythene tube and the volume made up to $4 \mathrm{ml}$ as with the acid digest.

The iron uptake of the tissue slices, $\mathrm{U}$, in $\mu \mathrm{g}$ iron per $100 \mathrm{mg}$ wet weight of tissue, was calculated from the formula

$$
U=\frac{A}{S} \times I \times \frac{100}{T W}
$$

where $\mathbf{A}=$ the number of counts per unit time of the acid digest $;=$ the number of counts per unit time of the standard solution; $I=$ the amount of iron in the standard solution expressed in micrograms; and $\mathrm{TW}=$ the tissue weight in milligram.

A total of 27 different specimens of tissue from 25 individuals were tested. These included the epithelial tissues-liver, thyroid, pancreas, and parotid gland and 
the non-epithelial tissues-striated muscle, smooth muscle (from bowel wall), myocardium, and spleen. Two different tissues were taken from the same patient in two instances (Table I).

\section{RESULTS}

The iron uptake by the various tissues tested is summarized in Table I. Table II shows that there is no significant difference between the $p \mathrm{H}$ values of the sera in which the transferrin was approximately $50 \%$ saturated and those in which the transferrin was approximately $90 \%$ saturated.

The uptake of ${ }^{59} \mathrm{Fe}$ from transferrin approximately $90 \%$ saturated was greater than that from transferrin approximately $50 \%$ saturated in all samples. This difference in uptake was statistically significant for samples of liver $(P<0.01)$ and thyroid $(\mathrm{P}<0.01)$ but was not significant for samples of striated muscle. When the uptake by liver was compared with that of thyroid no significant difference was found. The difference in uptake by the epithelial tissues was significantly greater than that of the nonepithelial tissues $(\mathrm{P}<0.05)$.
TABLE II

$p H$ VALUES OF SOME SERA IN WHICH TISSUES WERE INCUBATED

Reference Serum with Transferrin

No.

Approximately $50 \%$ Saturated

\begin{tabular}{lll}
\hline 23 & $7 \cdot 37$ & $7 \cdot 39$ \\
24 & $7 \cdot 45$ & $7 \cdot 48$ \\
25 & $7 \cdot 49$ & $7 \cdot 51$ \\
26 & $7 \cdot 35$ & $7 \cdot 36$ \\
27 & $7 \cdot 37$ & $7 \cdot 40$
\end{tabular}

There was considerable variation in the difference in the uptake of ${ }^{59} \mathrm{Fe}$ at the two degrees of transferrin saturation, not only between one tissue and another but between different samples of the same tissue.

The difference in uptake by liver no. $2(0.078 \mu \mathrm{g}$ 仓ै $\mathrm{Fe} / 100 \mathrm{~g}$ tissue) is much greater than that of spleen no. $26(0.010 \mu \mathrm{g} \mathrm{Fe} / 100 \mathrm{mg}$. tissue) from the same patient, and again the difference in uptake by liver no. $3(0.173 \mu \mathrm{g} \mathrm{Fe} / 100 \mathrm{mg}$ tissue $)$ is much greater than that of striated muscle no. $24(0.012 \mu \mathrm{g} \mathrm{Fe} / 100 \mathrm{mg}$. tissue) also from the same patient.

TABLE I

UPTAKE OF ${ }^{59}$ FE BY SLICES OF VARIOUS HUMAN TISSUES FROM TRANSFERRIN AT DIFFERENT PERCENTAGES OF SATURATION ${ }^{1}$

$\begin{array}{lll}\begin{array}{l}\text { Reference } \\ \text { No. }\end{array} & \text { Tissue } & \begin{array}{l}\text { Uptake of Iron from } \\ \text { Transferrin }\end{array}\end{array}$

Approximately $90 \%$ Saturated

Approximately $50 \%$ Saturated

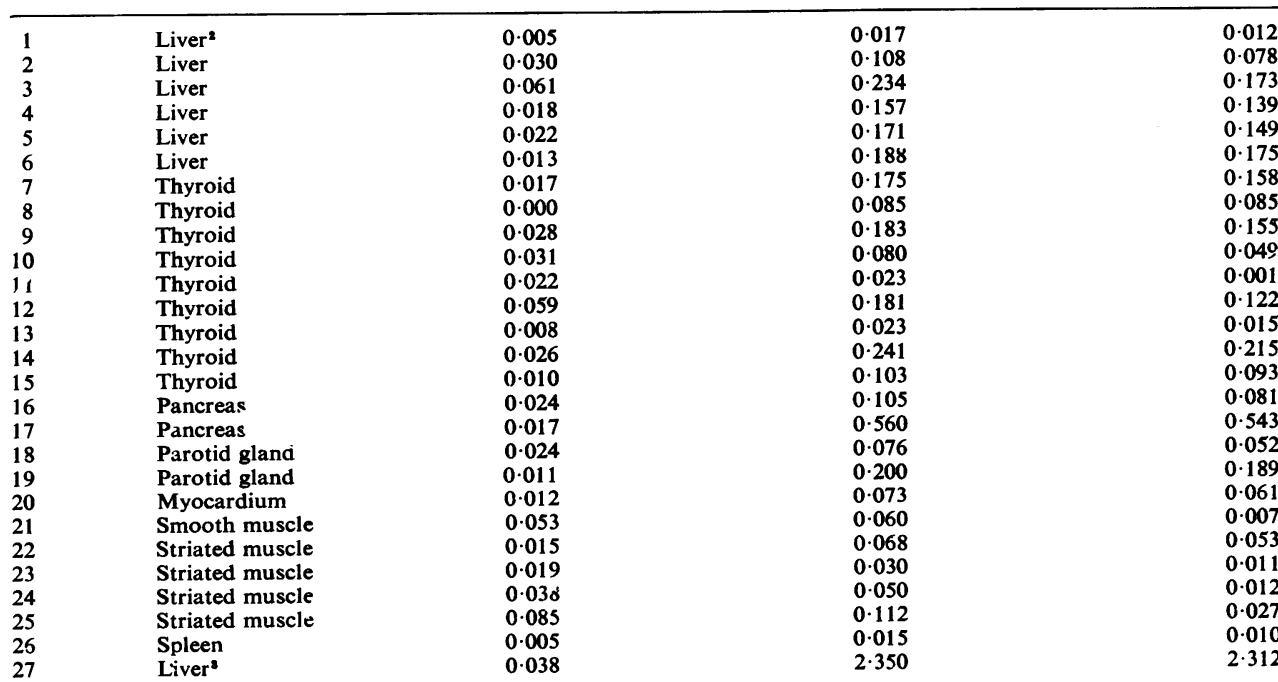

${ }^{1}$ Results expressed in $\mu \mathrm{g} \mathrm{Fe} / 100 \mathrm{mg}$ wet weight of tissue.

${ }^{2}$ Stainable iron in hepatic cells +++

'Patient had severe iron-deficiency anaemia.

Specimens 3 and 24 were from the same patient and specimens 2 and 26 were from the same patient.

The difference in uptake of iron (all samples except 27) from transferrin $90 \%$ saturated and from transferrin $50 \%$ saturated is significant $\frac{9}{10}$ ( $P<0.001)$.

The difference in uptake is significant for liver samples $(P<0.01)$ and thyroid samples $(P<0.01)$ but not for striated muscle $(P>0.05)$

There is no significant difference between the 'uptake' of liver and thyroid $(P>0.05)$.

The difference in 'uptake' by epithelial tissues is significantly greater than that of the non-epithelial tissues $(P<0.05)$. 
Liver specimen no. 27 is considered separately from the other liver specimens as the patient was suffering from severe iron-deficiency anaemia.

\section{DISCUSSION}

Only the difference in uptake of ${ }^{59} \mathrm{Fe}$ by tissues from the two serum samples is considered here, as the method used measured iron in the interstitial tissue as well as that incorporated into the tissue cells. It was impossible to say therefore how much of the ${ }^{59} \mathrm{Fe}$ found in a single specimen was due to cellular uptake and how much was due to non-specific trapping of radioactive serum. It is possible that the uptake of ${ }^{59} \mathrm{Fe}$ by tissues from the half saturated serum transferrin was due largely, if not entirely, to such non-specific trapping.

For simplicity, in the following discussion the difference in uptake of iron by the tissues from serum with the high saturation of transferrin and that with the low saturation is referred to as the 'uptake' by that tissue.

It appears from this experiment that certain human tissues take up iron from serum to a significantly greater extent when the transferrin is almost completely saturated than when it is only half saturated, thus confirming for human tissues the findings of Jandl et al (1959) on rat liver slices. The difference in uptake which was noted between epithelial and non-epithelial tissues is further confirmed by the fact that the uptake by one liver was appreciably greater than that by striated muscle from the same patient and the uptake by a second liver was greater than by spleen from the same patient.

The fact that the uptake by epithelial tissues is greater than by non-epithelial tissues could explain the heavy iron deposits found in the former in conditions with high transferrin saturation, such as haemochromatosis. The iron uptake by the sample of spleen was small yet in most cases of siderosis in the Bantu, and in many of haemochromatosis, the iron content of this organ may be considerable (Sheldon, 1935; Finch and Finch, 1955). The probable explanation is that the iron found in the spleen in these cases was not derived from serum but resulted from delay in releasing iron from the breakdown of haemoglobin in effete red cells. Such delay may be associated with infections and other toxic conditions (Cartwright, Lauristen, Humphreys, Jones, Merril, and Wintrobe, 1946; Laurell, 1947; Cartwright, and Wintrobe, 1949).

The absence of any significant difference in uptake between liver and thyroid suggests that the heavy deposits of iron found in the liver in subjects with siderosis may not be due to any specific affinity for iron by that organ but to its proximity to the site of entry of the iron into the body. This theory would presuppose that some of the absorbed iron on reaching the liver was not firmly bound to transferrin and was transferred to the hepatic cells in the same way as the iron from transferrin which was highly saturated. This situation might especially arise if absorption were rapid due to a diet very rich in iron, causing the transferrin to become saturated and resulting in the presence of unbound iron in the portal system.

The variation in uptake between different samples of the same tissue is striking. This value in liver sample no. 1 was very low, being only $0.012 \mu \mathrm{g}$ iron/ $100 \mathrm{mg}$ tissue, while in liver no. 27 it was $2.312 \mu \mathrm{g}$ iron/100 mg tissue. A similar variation was noted between samples of thyroid tissue: eg, in sample no. 11 the uptake was negligible while in sample no. 14 it was $0 \cdot 215 \mu \mathrm{g}$ iron $/ 100 \mathrm{mg}$ tissue.

A feature which possibly had some bearing on this in the liver samples was that heavy deposits of stainable iron were found in the hepatic cells of sample no. 1, whereas in sample no. 27 there was no stainable iron because the patient was suffering from severe iron-deficiency anaemia. This explanation could not, however, account for the variation in uptake by the thyroid samples, as stainable iron was not found in any of the thyroids tested. In thyroid the variation in uptake may be in some way related to activ ty of the thyroid follicles, because in sample no. 11 the follicles were very large and distended with colloid whereas in sample no. 14 the follicles were small and fairly normal looking.

Experiments by Saltman, Fiskin, and Bellinger (1956a), using rat liver slices, showed that ionic iron diffused into the hepatic cells and became bound to some entity within the cell. Further work by Saltman, Fiskin, Bellinger, and Alex (1956b) seemed to indicate that ferritin was the iron-binding entity. It seems, however, unlikely that variation in ferritin content is responsible for the variation in iron uptake in different samples of the same tissue because the uptake by the spleen sample from transferrin $90 \%$ saturated with iron was very small and spleen is known to be rich in ferritin (Granick, 1957; Bothwell and Finch, 1962; Harrison, 1964; MacLennan and Lewis, 1967).

Experimental work on rats (MacDonald, Jones, and Pechet, 1965) showed that folic acid deficiency associated with a diet rich in iron resulted in extrahepatic parenchymal deposits of iron. Rats on an iron-rich diet without folic acid deficiency did not have extrahepatic parenchymal iron deposits, even though in both groups there was a high percentage saturation of transferrin.

If folic acid deficiency alone were responsible for the extrahepatic epithelial deposits of iron it would 
be difficult to explain the results found in the present investigation. The results could be reconciled if folic acid deficiency caused an increased uptake of iron from serum only when the percentage saturation of transferrin was high and that all of the patients whose tissues were used in the present experiment were to some extent folic-acid-deficient. In such circumstances the folic acid deficiency theory of MacDonald et al (1965) would be compatible with the results found here. Indeed a variable degree of folic acid deficiency in the patients chosen for the experiment may have been responsible for the variability in iron uptake found in different specimens of the same tissue.

The findings appear to confirm previous evidence (Buchanan, 1967) that extrahepatic parenchymal deposits of iron in Bantu subjects with siderosis are at least partly dependent on high percentage saturation of transferrin. It seems possible that other factors, such as iron content of the cells, folic acid deficiency, or other metabolic activity of the cells, may also be important.

I am grateful to the following surgeons in Harari Hospital for providing biopsy material for this investigation: Professor J. Mynors, Mr W. Bartlett, Mr W. Gordon, Mr B. Hammar, and Mr J. M. White.

\section{REFERENCES}

Bothwell, T. H. (1964). In Iron Metabolism, edited by F. Gross. Springer, Berlin.
- and Finch, C. A. (1962). Iron Metabolism. Little, Brown, Boston. Churchill, London.

-, Jacobs, P., and Kamener, R. (1959). S. Afr. J. med. Sci., 24, 93.

_. and Mallett, B. (1955). Biochem. J., 59, 599.

Bradlow, B. A., Dunn, J. A., and Higginson, J. (1961). Amer. J. Path., 39, 221.

Buchanan, W. M. (1967). Faculty of Medicine Research Lecture, Series no. 1. University College of Rhodesia, Salisbury, Rhodesia

Cappell, D. F. (1958-59). Lect. sci. Basis Med., 8, 329.

Cartwright, G. E., Lauristen, M. A., Humphreys, S., Jones, P. J., Merrill, I. M., and Wintrobe, M. M. (1946). J. clin. Invest., 25, 81.

- and Wintrobe, M. M. (1949). Ibid., 28, 86.

Finch, S. C., and Finch, C. A. (1955). Medicine (Baltimore), 34, 381. Granick, S. (1957). In Biochemical Disorders in Human Disease, edited by R. H. S. Thompson, and E. J. King, p. 674. Churchill, London.

Harrison, P. M. (1964). In Iron Metabolism, edited by F. Gross Springer, Berlin.

Higginson, J., Gerritsen, 1., and Walker, A. R. P. (1953). Amer. J. Path., 29, 779.

Isaacson, C., Seftel, H. C., Keeley, K. J., and Bothwell, T. H. (1961). J. Lab. clin. Med., 58, 845.

Jandl, J. H., Inman, J. K., Simmons, R. L., and Allen, D. W. (1959). J. clin. Invest., 38, 161.

Laurell, C. B. (1947). Acta physiol. scand., 14, suppl. 46.

MacDonald, R. A., Jones, R. S., and Pechet, G. S. (1965). Arch. Path., $80,153$.

MacLennan, W. J., and Lewis, G. P. (1967). Clin. chim. Acta., 18, 371. Saltman, P., Fiskin, R. D., and Bellinger, S. B. (1956a). J. biol. Chem., 220, 741.

,,--- , and Alex, T. (1956b). Ibid., 220, 751.

Sheldon, J. H. (1935) Haemochromatosis. Oxford University Press.

Stadie, W. C., and Riggs, B. C. (1944). J. biol. Chem., 154, 687.

Surgenor, D. M., Koechlin, B. A., and Strong, L. E. (1949). J. clin. Invest., 28, 73.

Wainwright, J. (1957). S. Afr. J. Lab. clin. Med., 3, 1. 